\title{
Significance of external loop recorders (ELR) in diagnosis of disturbances in heart rhythm
}

\author{
Znaczenie zewnętrznego rejestratora pętlowego (ELR) w rozpoznawaniu \\ przyczyn kołatań serca
}

\begin{abstract}
JAGODA MŁYNARCZYK¹, B, D-F, MAŁGORZATA PORĘBA'², D-F, PAWEŁ GAĆ1, D-F,

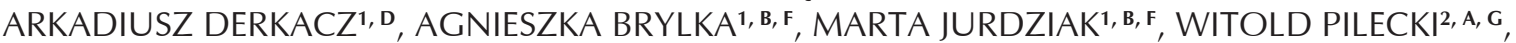
GRZEGORZ MAZUR ${ }^{1}$, D, G, MAŁGORZATA SOBIESZCZAŃSKA², A, G, RAFAŁ PORĘBA, A, c, D, G
\end{abstract}

${ }^{1}$ Department of Internal Medicine, Occupational Diseases and Hypertension, Wroclaw Medical University ${ }^{2}$ Department of Pathophysiology, Wroclaw Medical University

A - Study Design, B - Data Collection, C - Statistical Analysis, D - Data Interpretation, E - Manuscript Preparation, $\mathbf{F}$ - Literature Search, $\mathbf{G}$ - Funds Collection

Summary Background. Heart palpitations are frequently reported by patients but have non-specific character, which poses a principal diagnostic difficulty. There are several methods of ECG monitoring, however selection and duration of such recording should be guided by the expected time of repeated symptoms. External loop recorder (ELR) represents an external recording instrument in patients who have an inter-symptom interval $\leq 4$ weeks.

Objectives. This study aimed at evaluation of ELR usefulness in patients with periodic manifestation of heart palpitations and at evaluation of prevalence of arrhythmias in this group of patients.

Material and methods. The study was conducted on 48 patients, including 38 women and 10 men. Mean age of the patients was $48.5 \pm 18$ years. Duration of the monitoring period using ELR recorder varied from 3 to 10 days, depending on manifestation of subjective symptoms.

Results. Abnormalities in ECG record were detected in 33 patients $(68.75 \%)$. In the remaining 15 patients (31.25\%) ECG records were normal. Most frequently (in $77.08 \%$ patients) benign alterations were disclosed, including sinus tachycardia, premature supraventricular complexes and premature ventricular complexes, a group of disturbances defined as clinically significant was manifested in $27.08 \%$ of examined patients. Alterations of ischemic character accounted for $20.83 \%$ of disturbances. Conclusions. External loop recorder is an easy tool for diagnosing heart palpitations in case when Holter monitoring is not conclusive. The group of people in whom external loop recorders should be specially applicable are elderly individuals, due to the physiological changes in conduction system in the course of the aging process.

Key words: disturbances in heart rhythm, ECG monitoring, external loop recorder.

Streszczenie Wstęp. Kołatania serca stanowią częstą dolegliwość zgłaszaną przez pacjentów. Istotną trudność diagnostyczną stanowi ich niska swoistość. Istnieje kilka metod monitorowania EKG przydatnych w diagnostyce przyczyn kołatań serca. Przy doborze metody oraz czasu trwania zapisu należy kierować się przewidywanym czasem powtarzania się objawów. Zewnętrzny rejestrator pętlowy (ELR) znajduje zastosowanie u pacjentów, u których odstęp między objawami wynosi $\leq 4$ tygodnie. Cel pracy. Ocena przydatności ELR u pacjentów z okresową manifestacją kołatań serca w ocenie częstości występowania zaburzeń rytmu serca.

Materiał i metody. Badania przeprowadzono u 48 chorych, w tym 38 kobiet i 10 mężczyzn. Średni wiek pacjentów wynosił 48,5 \pm 18 lat. Czas trwania okresu monitorowania za pomocą ELR wahał się od 3 do 10 dni, w zależności od manifestacji objawów subiektywnych.

Wyniki. Nieprawidłowości w zapisie EKG stwierdzono u 33 chorych (68,75\%). U pozostałych 15 pacjentów (31,25\%) zapisy EKG były prawidłowe. Najczęściej (u 77,08\% chorych) zostały ujawnione zmiany łagodne, w tym tachykardia, przedwczesne pobudzenia nadkomorowe i komorowe, zaburzenia z grupy definiowanej jako istotne klinicznie ujawniły się u 27,08\% badanych pacjentów. Zmiany o charakterze niedokrwiennym stanowiły 20,83\% zakłóceń.

Wnioski. Zewnętrzny rejestrator pętlowy stanowi łatwe w obsłudze narzędzie do diagnozowania kołatań serca, zwłaszcza w przypadku, gdy wynik badania EKG metodą Holtera jest niejednoznaczny. Grupę osób, u których ELR powinny być szczególnie przydatne, stanowią osoby w podeszłym wieku, ze względu na zmiany w układzie bodźcowo-przewodzącym występujące fizjologicznie w trakcie procesu starzenia.

Słowa kluczowe: zaburzenia rytmu serca, elektrokardiogram, zewnętrzny rejestrator pętlowy.

Fam Med Prim Care Rev 2015; 17(3): 193-196

\section{Background}

Cardiovascular diseases account for $45 \%$ deaths in Poland [1]. A symptom of heart palpitation is frequently reported by patients but its non-specific character poses a principal diagnostic difficulty. It should be mentioned that palpitations suggest manifestation of disturbances in heart rate, either requiring no intense therapeutic management or posing threat to the patient's health and life. Therefore, the patients complaining of palpitations require ECG monitor- 
ing. One of the main goals should be the determination of correlations between manifestation of the symptoms and arrhythmias, however it sometimes happens that patients may be symptomless, or present only minor or atypical signs of arrhythmia [2].

Arrhythmias are more common in people of older age. This fact is connected with physiological changes present in conduction system of the heart and frequent co-existence of coronary heart disease, as well as, arterial hypertension in elderly individuals. Aging of the organism is associated with the degenerative process of the sinus node resulting in fibrosis. Diagnosis of disturbances in heart rhythm may be conducted in ambulatory conditions in patients of the group of low risk of cardiovascular events or a sudden cardiac death (SCD). At present there are several methods of long term ECG monitoring while selection and duration of such recording should be guided by the expected time of repeated symptoms [3].

External loop recorder (ELR) represents an external recording instrument with two bipolar skin surface electrodes, placed on patient's chest. The registered ECG record is stored in the form of a loop, i.e. continuously collecting new data over the earlier ones. Activation of the instrument results in "freezing" of the till now registered record and it is executed by the patients in the moment of the symptom manifestation. An appropriate software allows to individually adjust the time in which the ECG record is stored. According to the new guidelines external loop recorder is indicated when symptoms occur in week intervals (up to 4 weeks) optional to 7 days of Holter monitoring and in case of symptoms occurring in month intervals 14 to 30 days of external loop recorder should be applied [3,4]. Discussion on usefulness and credibility of ELR always involves its comparison to monitoring using the traditional Holter method, optimum duration of monitoring and an appropriate registration of the record by the examined patients.

\section{Objectives}

This study aimed at evaluation of ELR usefulness in patients with periodic manifestation of heart palpitations and at evaluation of prevalence of arrhythmias in this group of patients.

\section{Material and methods}

The study was conducted on 48 patients, including 38 women $(79.16 \%)$ and 10 men. Mean age of the patients was $48.5 \pm 18$ years. The patients participating in the study were admitted to the Holter Laboratory of Pathophysiology Department, Wroclaw Medical University. ELR CardioCall ST80 (Del Mar Reynolds Medical, Hereford, UK) and CardioConnect software were used.

Duration of the monitoring period using ELR recorder varied from 3 to 10 days, depending on manifestation of subjective symptoms. When the manual recording function is activated by the patient, recent $1 \mathrm{~min}$ fragment of ECG is stored. The clinically significant disturbances included non-sustained ventricular tachycardia (nsVT), paroxysmal supraventricular tachycardia (PSVT) and atrial fibrillation (AF). Sinus tachycardia (ST), supraventricular extrasystoles (SVES), premature ventricular contractions (PVC) were classified as benign disturbances. A group of possible ischemic events (a lowered ST segment and a negative T wave) was also distinguished.

The patients were also asked to fill a questionnaire, pertaining to accompanying diseases (Table 1).

In all of the patients 24-hour Holter monitoring was previously carried out (Table 2 ).

\begin{tabular}{|l|l|}
\hline Table 1. Co-morbidities in patients \\
\hline Disease & Number of patients \\
\hline Arterial hypertension & 19 \\
\hline Disease of thyroid gland & 8 \\
\hline Ischemic heart disease & 6 \\
\hline Depression & 6 \\
\hline Cancer & 4 \\
\hline Diabetes mellitus & 4 \\
\hline
\end{tabular}

Table 2. Results of the 24-hour Holter monitoring

\begin{tabular}{|l|l|}
\hline ECG changes & Number of patients \\
\hline Sinus rhythm & 18 \\
\hline $\begin{array}{l}\text { Paroxysmal supraventricular tachy- } \\
\text { cardia }\end{array}$ & 8 \\
\hline Premature ventricular contractions & 4 \\
\hline Right bundle branch block & 1 \\
\hline Atrial fibrillation & 1 \\
\hline
\end{tabular}

Statistical analysis was conducted using Statistica 9 software (StatSoft Polska). For quantitative variables arithmetic means $(\mathrm{X})$ and standard deviations (SD) of estimated variables were calculated in the studied groups. Results of qualitative variables were presented in the form of percentage.

\section{Results}

Abnormalities in ECG record were detected in 33 patients $(68.75 \%)$. In the remaining 15 patients $(31.25 \%)$ ECG records were normal. Most frequently (in $77.08 \%$ patients) benign alterations were disclosed, including sinus tachycardia, premature supraventricular complexes (SVPC) and premature ventricular complexes (PVCS), group of disturbances defined as clinically significant was manifested in $27.08 \%$ of examined patients. Alterations of ischemic character accounted for $20.83 \%$ of disturbances (Table 3 ).

\begin{tabular}{|l|l|}
\hline \multicolumn{2}{|l|}{ Table 3. ECG changes diagnosed with ELR } \\
\hline ECG changes & Number of patients \\
\hline Non-sustained ventricular tachycardia & 2 \\
\hline Atrial fibrillation & 3 \\
\hline Negative T wave & 3 \\
\hline Lowered ST segment & 7 \\
\hline $\begin{array}{l}\text { Paroxysmal supraventricular tachy- } \\
\text { cardia }\end{array}$ & 8 \\
\hline Supraventricular extrasystoles & 10 \\
\hline Ventricular extrasystoles & 10 \\
\hline
\end{tabular}

In 14 patients (29.79\%) ECG record disclosed more than a single abnormality (Table 4).

\begin{tabular}{|l|l|}
\hline \multicolumn{2}{|l|}{ Table 4. Frequency of changes diagnosed with ELR } \\
\hline Number of ECG changes & Number of patients \\
\hline 1 & 16 \\
\hline 2 & 12 \\
\hline 3 & 2 \\
\hline 4 & 1 \\
\hline 5 & 2 \\
\hline
\end{tabular}


The percentage distribution of gender was similar both in the group with ECG alterations and in those with normal ECG record (women comprised, respectively, $82 \%$ and $73 \%)$. In the group of women ECG changes were detected in the total of $71 \%$, and in the group of men in $60 \%$ of examined patients.

\section{Discussion}

Development of ECG monitoring technology provides a wide scope of possibilities, however diagnosis of arrhythmia sometimes becomes a challenge. This is linked mainly to irregularity, paroxysmal and variable character of manifestation in disturbances of heart rhythm. This makes detecting the appearance of symptoms difficult and unfavourably affects patient's motivation for further studies. Nevertheless, with poor patient compliance it is not easy to reach the suitable diagnostic goal of establishing a correlation between symptoms and arrhythmia [2].

The first stage of diagnosis includes accurately collected anamnesis and physical examination. Subsequent management of the patient should be integrated: general laboratory tests are required, cardiologic examination (including ECG monitoring and echocardiography) and, sometimes, evaluation of neurological condition.

Currently, the potential diagnostic tool may be selected among Holter monitoring, external event recording and the implantable, internal loop recorder (ILR). The principal limitation involves prolonged duration of the tests, which could influence patient's motivation but also exposes the patient to risk of trauma upon fainting or even risk of death in cases of ventricular arrhythmia $[4,5]$.

Generally, external event recorders play a marginal role in ESC recommendations related to diagnosis and management of syncope, but the devices are mentioned as useful in atrial fibrillation recommendations [5]. When arrhythmia or therapy-related symptoms are suspected, monitoring with Holter recording or external event recorders should be considered. There also was mentioned that in patients with suspected symptomatic AF, additional ECG monitoring should be considered in order to document it (Ila, B class recommendation), and also additional ECG monitoring was suggested to be considered for detection of 'silent' AF in patients who may have sustained an AF-related complication.

Generally, several systems of ECG ambulatory monitoring are available: conventional ambulatory Holter monitoring, in-hospital monitoring, event recorders, external or implantable loop recorders, and remote (at home) telemetry. External loop recorders should be rather considered in patients who have an inter-symptom interval $\leq 4$ weeks [5]. ECG monitoring should be indicated in people with syncope only when there is a high pre-test probability of identifying an arrhythmia associated.

External loop recorders have a loop memory that continuously records and deletes ECG, and activated by the patient, after a symptom, normally with 5-15 min of preactivation ECG, which then is stored [5].

According to the guidelines for syncope previous studies gave equivocal results about the usefulness of external loop recorders: one study showed that external retrospective loop recorders allowed ECG documentation of syncope in up to $25 \%$ of the patients monitored for 1 month, whereas in another external loop recorders were not useful $[6,7]$. There is, however growing data that external loop recorders may have an increased diagnostic yield, when compared with Holter monitoring [8]. Application of ELR is also recommended in diagnosis of cardiac palpitation, and for the purpose of identifying causes of primary bradycardia manifestation $[2,7,8]$.
In the present study external event recorders permitted to correlate ECG changes and clinical signs and symptoms in $68.75 \%$ patients. In $50 \%$ patients, subjected earlier to $24-\mathrm{h}$ monitoring by Holter's method, a new diagnosis of nsVT or $\mathrm{AF}$ was established, belonging to the group of clinically significant diagnoses.

The most common pathology in the examined group of patients was sinus tachycardia and it should be evaluated in respect to circumstances in which it appeared, physical exertion and stress. The second in frequency premature supraventricular complexes may induce symptoms due to the altered cardiac rhythm.

In $20.83 \%$ of patients transient myocardial ischemia was detected, which appeared in the course of sinus tachycardia episodes. This may be of significance in observations of patients with coronary artery disease or suspicion of the disease.

Previous studies indicated a variable duration of the time of ECG monitoring, ranging from 14 to even 30 days $[9,10]$. Such an extended monitoring results in a significant increase in diagnoses as compared to monitoring with Holter. A similar percentage of diagnoses has been obtained $(8 \%)$, similarly to other studies estimating efficacy of such a management but a markedly lower than that upon longer observation (in this study: 62\%) [11]. This finding is valuable due to the fact that the data relevant for the same population directly illustrate advantages linked to extended duration of examination. Extension of the examination from two to three weeks resulted in reduction of its efficacy from $96 \%$ to $79 \%$ [9]. Duration of the present observation was shorter (3 to 10 days) but, nevertheless, the authors reached the percentage of diagnosis of $68.75 \%$. This fitted the range of results obtained by other authors, i.e. $56 \%$ to $75 \%[10,12]$. The shorter duration of examination reflected the independent termination of the examination by the patients after they had experienced symptoms of any significance.

The extended duration of examination, as compared to traditional ECG monitoring by Holter method, has increased the number of diagnoses. In the patients' subgroup examined by Holter's technique, any alterations in ECG pattern were detected in $29.62 \%$ of patients, while application of ELR has allowed to detect the abnormalities in $68.75 \%$ of examined patients.

The diagnosis of symptoms suggesting an arrhythmic background can be concluded to require a multi-stage approach. Ambulatory, long-term monitoring of cardiac rhythm became a basic accessory study, permitting to confirm finally a correlation between reported complaints and disturbances in cardiac rhythm. Application of ELR in diagnosis of cardiac palpitation represents an effective approach, permitting to precisely link the symptoms to ECG record. In the presented study alterations in cardiac rhythm were manifested in almost $70 \%$ examined patients. According to the present authors, application of ELR should be considered to represent the management of choice when heart palpitation is of unstable character and becomes manifested less frequently than once every 4 weeks. However, the group of patients in whom implementation of such a diagnostic procedure is useful is restricted and such an implementation requires engagement of both the physician and the patient.

The discussed paper has some limitations. One of them is the lack of information about physical activity, stress and arrhythmogenic agents, potentially having some influence on arhhythmia pathogenesis. Moreover, the thyroid gland diseases, present in patients from the study group, could be more precisely characterized with determining levels of thyroid hormones, which potentially could have impact on the incidence of some types of ECG changes diagnosed with ELR. On the other hand, the mentioned limitations may encourage to lead further studies in this area. 


\section{Conclusions}

External loop recorder is an easy tool for diagnosing heart palpitations in case when Holter monitoring is not conclusive. The present study showed that in majority of patients, around $70 \%$ presented with different types of ar- rhythmias, mainly mild such as sinus tachycardia premature supraventricular and ventricular complexes and paroxysmal supraventricular tachycardia. The group of people in whom external loop recorders should be specially applicable are elderly individuals, due to the physiological changes in conduction system in the course of the aging process.

Source of funding: This work was funded by the authors' resources.

Conflict of interest: The authors declare no conflict of interests.

\section{References}

1. Gwiazda E, Mastalerz-Migas A, Szyber P. Analiza częstości występowania poszczególnych zaburzeń lipidowych wśród pacjentów z rozpoznaną dyslipidemią. Fam Med Prim Care Rev 2014; 16: 101-102.

2. Subbiah R, Gula LJ, Klein GJ, et al. Syncope: review of monitoring modalities. Curr Cardiol Rev 2008; 4: 41-48.

3. Baranowski R, Bieganowska K, Cygankiewicz I, i wsp. Wytyczne dotyczące wykonywania długotrwałych rejestracji EKG. Kardiol Pol 2013; 71(Suppl IX): 225-242.

4. Krahn AD, Klein GJ, Yee R, et al. The use of monitoring strategies in patients with unexplained syncope-role of the external and implantable loop recorder. Clin Auton Res 2004; 14(Suppl. 1): 55-61.

5. Moya A, Sutton R, Ammirati F, et al. Guidelines for the diagnosis and management of syncope (version 2009). Eur Heart J 2009; 30: $2631-2671$.

6. Linzer M, Pritchett EL, Pontinen M, et al. Incremental diagnostic yield of loop electrocardiographic recorders in unexplained syncope. Am J Cardiol 1990; 66: 214-219.

7. Schuchert A, Maas R, Kretzschmar C, et al. Diagnostic yield of external electrocardiographic loop recorders in patients with recurrent syncope and negative tilt table test. Pacing Clin Electrophysiol 2003; 26: 1837-1840.

8. Rockx MA, Hoch JS, Klein GJ, et al. Is ambulatory monitoring for "community-acquired" syncope economically attractive? A cost-effectiveness analysis of a randomized trial of external loop recorders versus Holter monitoring. Am Heart J 2005; 150: 1065.

9. Hoefman E, van Weert HC, Boer KR, et al. Optimal duration of event recording for diagnosis of arrhythmias in patients with palpitations and light-headedness in the general practice. Fam Pract 2007; 24: 11-13.

10. Gula LJ, Krahn AD, Massel D, et al. External loop recorders: determinants of diagnostic yield in patients with syncope. Am Heart J 2004; 147: 644-648.

11. Gula LJ, Klein GJ, Zurawska U, et al. Does familiarity with technology predict successful use of an external loop recorder? The loop recorder technology cognition study (LOCO). Pacing Clin Electrophysiol 2009; 32: 466-472.

12. Reiffel JA, Schwarzberg R, Murry M. Comparison of autotriggered memory loop recorders versus standard loop recorders versus 24-hour Holter monitors for arrhythmia detection. Am J Cardiol 2005; 95: 1055-1059.

Address for correspondence:

Dr hab. n. med. Rafał Poręba, prof. UMW

Department of Internal Medicine, Occupational Diseases and Hypertension

Wroclaw Medical University

Borowska 213

50-556 Wroclaw

Poland

Phone: +48 71 736-40-00

E-mail: sogood@poczta.onet.pl

Received: 13.05.2015

Revised: 06.06.2015

Accepted: 16.06.2015 